\title{
Review
}

\section{Our Working Point of View of Tau Protein}

\author{
Jesús Avila ${ }^{\mathrm{a}, \mathrm{b}, *}$

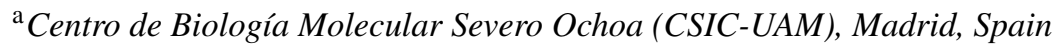 \\ ${ }^{\mathrm{b}}$ CIBERNED, Madrid, Spain
}

Accepted 3 August 2017

\begin{abstract}
Tau protein, which was discovered in Prof. Kirschner's laboratory in 1975, has been the focus of my research over the last 40 years. In this issue of the Journal of Alzheimer's Disease commemorating its 20th year of publication, I will provide a short review of some of the features of my relationship with tau.
\end{abstract}

Keywords: Alzheimer's disease, microtubules, neurons, tau

\section{INTRODUCTION}

Cellular shape is determined mainly by a cytoskeletal component, namely microtubules. These are fibrillar polymers composed of tubulin and their polymerization-depolymerization is a highly dynamic process (for a review, see [1]). If the probability of polymerization or depolymerization were equal in every direction inside a cell, the resulting shape would be a sphere [1]. However, when microtubules are stabilized without depolymerization in a specific direction, a cytoplasmic extension forms [2]. In cells with a complex morphology, like neurons, these cytoplasmic extensions are known as axons and dendrites, and they are characterized by the presence of stable (less dynamic) microtubules. Thus, it was of interest to determine the reason why neuronal microtubules show greater stability.

Tubulin is the main protein found in brain cells (Fig. 1), accounting for around 20\% of the total soluble protein present in a brain homogenate. This huge amount of protein facilitates the in vitro polymerization of microtubules from a brain extract [3]. Protein characterization of these polymerized brain

\footnotetext{
*Correspondence to: Jesús Avila, Centro de Biología Molecular Severo Ochoa (CSIC-UAM), 28049 Madrid, Spain; CIBERNED, 28031 Madrid, Spain. E-mail: javila@cbm.csic.es.
}

microtubules revealed the presence of tubulin and some microtubule-associated proteins (MAPs). Later, it was shown that MAPs, which are responsible for brain microtubule stabilization, can maintain the assembled polymers [4]. Among these MAPs, the one with the fastest electrophoretic mobility is known as tau factor [5].

\section{BINDING OF TAU TO TUBULIN}

In 1986, it was found that the C-terminal region of tubulin subunits are cleaved by digestion with the protease subtilisin and that the resulting truncated tubulin is unable to bind MAPs, including tau protein [6]. This C-terminal region of tubulin is rich in acidic residues and is thus negatively charged. Two years later, tau cDNA was cloned and the sequence of tau protein was revealed. It was then shown that the tau region involved in the binding to tubulin contained some similar, but not identical, repeated sequences enriched in basic (positively charged) residues [7]. On the basis of these observations, it was proposed that the tau-tubulin interaction was an ionic interaction between a basic and an acidic region of the tau and tubulin molecules, respectively (Fig. 2). 
A

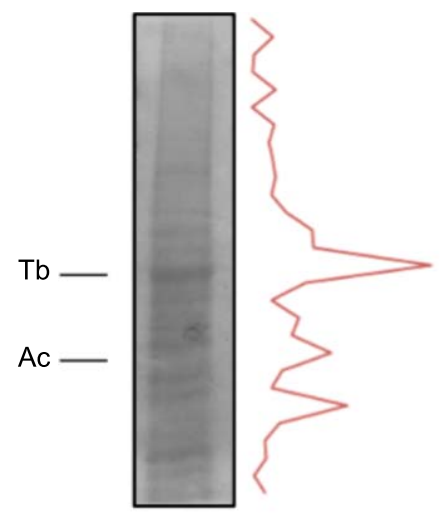

B

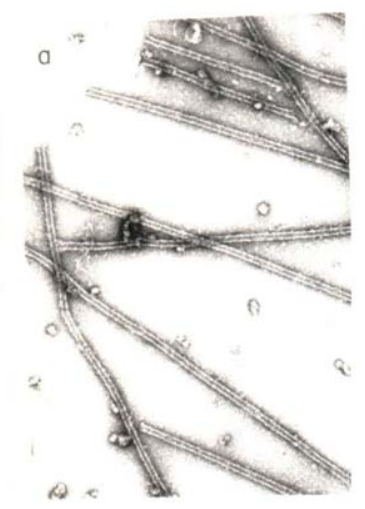

C

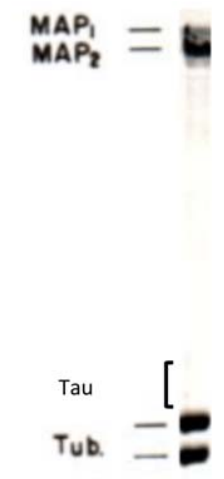

Fig. 1. In vitro polymerization of brain microtubules. Protein characterization. A) A porcine brain extract shows that tubulin (Tb) is the major protein present. Also, actin (Ac) is found in a high proportion. B) Electron micrograph of in vitro polymerized microtubules from porcine brain. C) Protein characterization of porcine brain polymerized microtubules by gel electrophoresis.

\section{Tubulin $(\alpha, \beta)$}

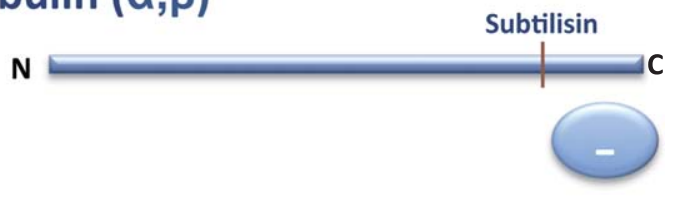

Tau

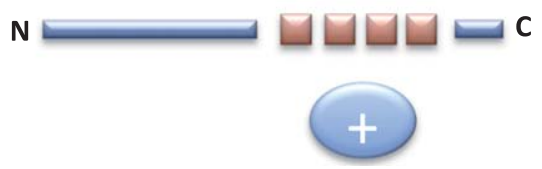

Fig. 2. Interaction tubulin-tau. The C-terminal (-, anionic) region of tubulin can bind to the tau $(+$, cationic) repeats present in the C-terminal half of tau protein.

\section{THE BINDING OF TAU ISOFORMS TO TUBULIN}

Human tau is expressed from a single gene (mapt) located at chromosome 17 that is translated into nuclear RNA and, after RNA splicing, it yields 16 exons. However, two of these ( 0 and 14$)$ are not translated into protein [8]. Mapt nuclear RNA is spliced in different ways and results in the appearance of various protein isoforms. This alternative splicing is regulated by several proteins [9].

Tau in the central nervous system contains isoforms that include exons $1,4,5,7,9,11,12$, and 13. In addition, some isoforms contain or lack exons 2, 3, and 10 [8]. Those containing exon 10 are known as tau $4 \mathrm{R}$ isoforms while those lacking it are referred to as tau $3 \mathrm{R}$. Tau present in the peripheral nervous system contains exons $4 \mathrm{a}, 6$, and 8 [8].

Tau protein has various isoforms that are translated from different mRNAs generated by alternative splicing [10]. To test the tubulin-binding capacity of the different isoforms, we used gel electrophoresis to fractionate all the isoforms isolated from a brain cell extract and that arose from alternative splicing or by post-translational modifications. We were able to fractionate tau isoforms into eight distinct electrophoretic bands (Fig. 3A). The nature of each band was further characterized. Curiously, those with a lower electrophoretic mobility (odd numbers) (Fig. 3B) showed a higher affinity for microtubules than the others (even numbers). These microtubule-binding isoforms are probably modified by phosphorylation, since their electrophoretic mobility increases upon phosphatase treatment and the isoforms with odd numbers become even numbers. However, the site modified and the kinase involved in the modification remain unknown. This preferential binding [11] could be explained by the modification causing the opening of the so-called tau paper-clip confirmation [12]. However, other conformational changes, involving the ends of the tau molecule, cannot be excluded [13].

\section{LOCALIZATION OF TAU IN NEURONS}

Tau, a microtubule-binding protein, is found mainly in the cytoplasm, although its presence in the 
A

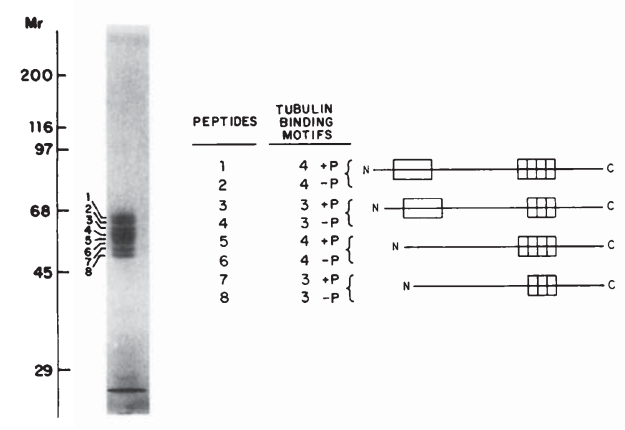

B

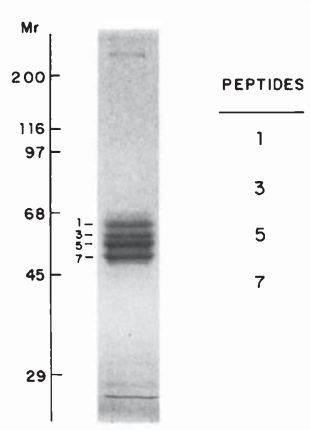

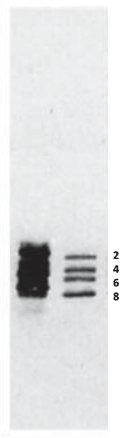

$-+$

phosphatase

Fig. 3. Binding of tau isoforms to polymerized microtubules. A) Porcine brain tau isoforms can be fractionated by gel electrophoresis into eight distinct peptides. The odd-numbered residues are phosphorylated whereas the even-numbered ones are not. B) Odd-numbered tau peptides can bind to microtubules and they become even-numbered upon alkaline phosphatase treatment (see [11]).

cell nucleus [14, 15], where it can bind to nucleic acids $[16,17]$, and at the membrane $[18,19]$ has also been reported.

In neurons, tau is found mostly in the axon [20], although its localization in the somatodendritic compartment, including dendritic spines, has been described [21].

In axons, tau regulates the localization and function of end-binding protein 1 and 3 (EB1/3), a protein involved in axonal navigation [22], and also mitochondrial axonal transport [23].

\section{TAU BINDING TO OTHER MOLECULES}

We have analyzed the binding of tau to tubulin or to itself, but also its interaction with actin [24], heparin [25-27], muscarinic receptors M1/M3 [28], zeta 14-3-3 protein [29], EB 1/3 [22, 30], deacetylase HDAC6 [31, 32] and ferritin [33]. A scheme of the tau regions involved in some of these interactions is shown in Fig. 4.

\section{TAU IN PAIRED HELICAL FILAMENTS}

From 1975 (tau discovery [5]) to 1986, only a small number of groups worldwide were working on tau. However, the seminal discovery made by Iqbal's group in 1986 [34] describing the presence of tau in the paired helical filaments (PHFs) of the brains of Alzheimer's disease (AD) patients-an observation that was rapidly confirmed $[35,36]$-changed the scenario. To determine whether tau is a PHFassociated protein or the core protein of PHFs, it was then tested whether highly purified tau protein in vitro was able to polymerize into filaments similar to PHFs. Thus, in 1986, we achieved a positive result indicating the assembly of highly purified tau into PHF-like structures [37, 38]. Later on, this result was confirmed [39], and it was also reported that the main component of PHFs isolated from AD patients is tau protein $[40,41]$.

Two laboratories almost simultaneously showed that tau polymerization is facilitated by the presence of heparin $[26,42]$ and also that the tubulin binding-

\section{Tau molecule}

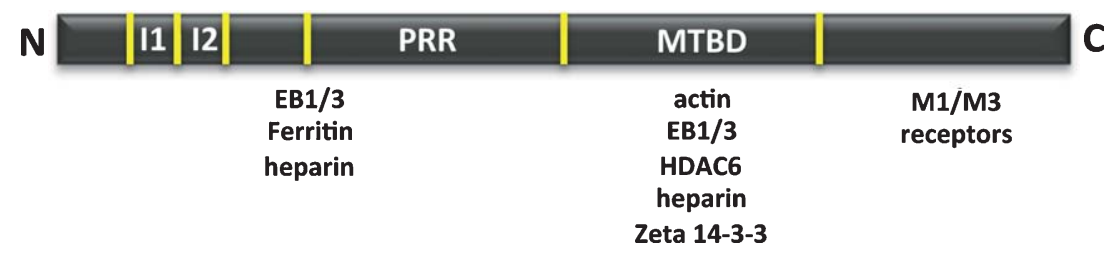

Fig. 4. Other tau-associated proteins. Map of the interaction of tau regions with various molecules, such as actin, heparin, muscarinic receptor, zeta 14-3-3 protein, EB1/3 proteins, deacetylase HDAC6 and ferritin. 
tau region is involved in tau self-assembly [26]. We reported that VQIVYK hexapeptide (residues 306-311) or the similar one VQIINK (residues 275-280) plays an important role in tau selfassembly. However, in the presence of heparin, we found that peptide KSKIGSTENLKHQPGGGKV (residues 257-275), which lacks these hexapeptides, forms fibrillar polymers [26].

Furthermore, we described that another posttranslational modification, namely glycation, facilitates the assembly of PHFs into larger structures [43], like neurofibrillary tangles, one of the two main aberrant structures found in the brains of $\mathrm{AD}$ patients [44].

\section{TAU TOXICITY}

A main feature of some tauopathies, like $A D$, is an increase in the level of intracellular tau [39]. In some of these tauopathies, aging is a major risk factor. During aging, a decrease in tau protein turnover may result in protein accumulation-which in turn favors post-translational modifications, such as phosphorylation (see below) and/or protein aggregation-and leads to increased proteotoxicity. At the level of protein aggregation, it has been widely debated whether smaller tau aggregates are more toxic than larger ones [45]. The jury is still out on this question.

\section{EXTRACELLULAR TAU}

The brains of AD patients show an increase in tau protein (in the unmodified and phosphorylated or aggregated form) [46]. This increase could occur mainly though a decrease in tau turnover rather than tau expression. It was proposed that such an increase results in cell death or tau secretion to the extracellular medium $[47,48]$. Tau secretion occurs through membrane vesicles or in a nacked form [48]. In both cases, the result is the presence of extracellular tau [47]. This extracellular protein (in monomeric form) binds to neuron receptors; an interaction that results in increased the levels of intracellular calcium [28]. The neuronal receptors that bind to tau protein were identified as muscarinic (M1, M3) receptors [28, 49].

On the other hand, extracellular aggregated or truncated tau is also toxic for neurons $[50,51]$ and can propagate from one brain region to another [51]. In this case, the entry of extracellular tau to the neuron may occur via macropinocytosis [52] (Fig. 5).
A

\section{Macropinocytosis?}

i)
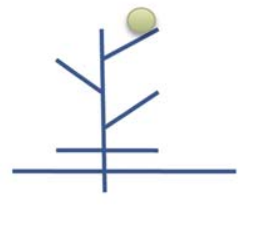

ii)

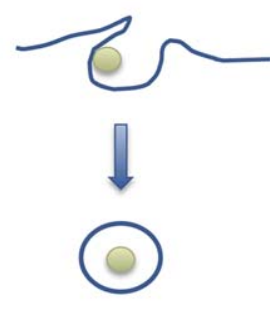

B

\section{M1/M3 muscarinic receptor}

i)

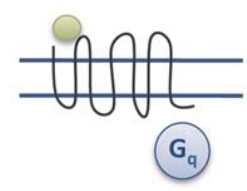

ii)

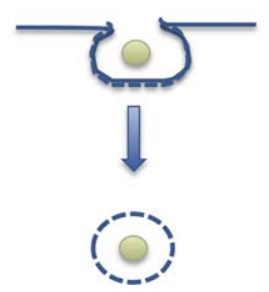

Fig. 5. Tau endocytosis. A) Macropinocytosis could be the way by which aggregated tau interacts with neurons to go into the cell whereas (B) soluble tau may interact with the M1/M3 muscarinic receptors present in neurons (see text and [28, 52]).

Indeed, in 2006, we proposed that extracellular tau propagates from neuron to neuron [47], a research field (tau propagation) in which we have also been working [28, 47, 53] (Bolos $\mathrm{M}$ et al., unpublished).

\section{TAU PHOSPHORYLATION}

One of the main features of $\mathrm{AD}$ is increased tau phosphorylation [46, 54]. Several protein kinases are involved in this process [55], but one of them, GSK3 $\beta$, also known as tau kinase I [56], is the one that modifies a greater number of sites in the tau molecule [57]. In this regard, we raised a conditional transgenic mouse overexpressing GSK3 $\beta$, under a promoter that facilitates the expression of the kinase at the forebrain [58].

In this transgenic mouse, tau was phosphorylated and clear age-related damage at the dentate gyrus was found [58]. This damage correlated with cognitive impairment [59] and some morphological changes in the newborn neurons present at the dentate gyrus [60]. The morphological changes in dendrites of granular cells (present at dentate gyrus) led to decreased connectivity of the newborn neurons with the neuronal network [60]. Also, a clear decrease in the number of dendritic spines was observed [60], although when 
the transgenic mice were placed in an enrichment environment some spine loss was reversed [60, 61].

Thus, an increase in the level of intracellular or extracellular tau is toxic for neurons. In this regard, a therapeutic strategy to decrease (or eliminate?) the presence of tau would be valuable.

\section{THE CONSEQUENCES OF TAU ABSENCE}

To date, mainly two tau knockout (KO) models have been used $[62,63]$. While general changes in phenotype were not observed in either, clear differences between the expression of phosphorylated (non-functional) tau in transgenic (Tg GSK3) mice and the lack of tau in tau KO mice were found. With respect to the newborn neurons of the tau $\mathrm{KO}$, no major alterations in dendritic morphology were found [64], but some changes in the number and localization of dendritic spines were observed [64]. However, these changes differed to those reported for the $\mathrm{Tg}$ GSK3 mouse model [60, 64]. In Tg GSK3 mice, the loss of dendritic spines was reversed when these animals were exposed to an enrichment environment [60]. However, the absence of tau impaired the adaptation of newborn neurons to such an environment and, also, tau protected newborn neurons from acute stress-induced impairments that may affect spine number [64]. In other words, tau protein is necessary to allow the plastic modulation of adult hippocampal neurogenesis (which takes place in the dentate gyrus) exerted by both positive and negative external stimuli. This lack of synaptic plasticity in tau KO mice correlates with a decrease in the number of spines at the distal region of the apical dendrites of newborn granule neurons (Fig. 6) [64, 65] (see also Kimura et al. [66]).

It is known that tau localizes in spines [21] and that the absence of tau in spines bearing glutamate (NMDA) receptor subunit GluN2B prevents the toxic effect of amyloid- $\beta$ peptide $(A \beta)$ when it binds to these NMDA receptors [21]. Curiously, not only does the absence of tau prevent $A \beta$ toxicity but also tau phosphorylation by GSK3 $[67,68]$ or another kinase (p38k) [69] at a specific residue (serine 205) [69]. More recently, it has been proposed that phosphorylation of tyrosine 18 of tau by fyn kinase also blocks $\mathrm{A} \beta$ toxicity [70].

Also, it has been shown that tau deletion does not result in lethality or in neurodegeneration. At the level of the whole organism, the lack of tau can result in an increase in the duration of wakefulness and a decrease in NREM sleep time [71], brain insulin resistance

\section{Changes in Tau k.o. (spines at the distal region of apical dendrites of DG granule neurons)}

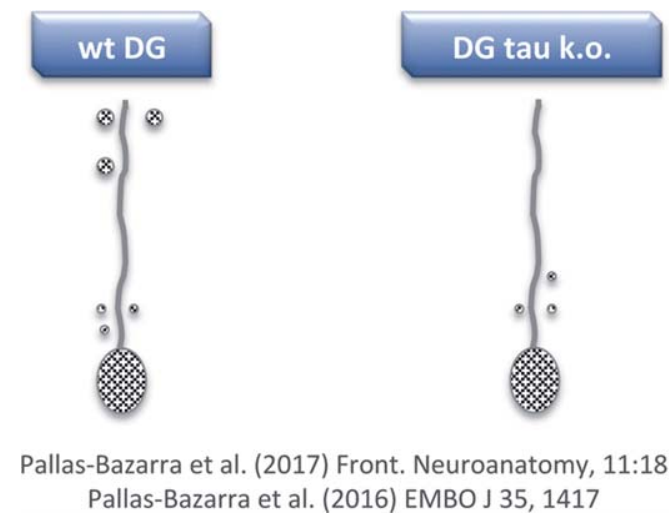

Fig. 6. Loss of dendritic spines in some neurons of tau KO mice. Distal regions of apical dendrites of newborn granule neurons from tau $\mathrm{KO}$ mice show a decrease in dendritic spines compared to wild-type mice.

[72] (see also the pioneer work of Planel et al. [73] and the comment on it [74]), and the development of some features related to Parkinson's disease [75]. However, I do not wish to focus this review on the role of tau in this or other disorders like Huntington's disease [76] or other tauopathies. What I will briefly mention is a recent study involving the presence of a specific SNP of tau gene in educational attainment [77]. It has been suggested that the presence of this SNP facilitates the expression of a non-coding RNA (ncRNAMAPTAS1) [78] that may regulate (decrease) tau RNA level [79]. This notion would support the idea that low levels of tau preserve cognition [80]. However, to maintain protein homeostasis [81], not only should the amount of tau be considered but also the "quality" or origin of the tau. Recently, the possible causes for the exceptional vulnerability of humans to AD have been discussed [82]. Given that one of these causes is postulated to be the presence of a specific feature in the structure of human tau, we are currently analyzing these structural differences, testing tau from human, cow, mouse syrian hamster, etc. [83], following the studies of other laboratories $[84,85]$.

\section{TAU AT THE SYNAPSES}

Intracellular tau, present at the dendritic spines, facilitates $A \beta$ toxicity [21], and extracellular tau may have a toxic effect on the presynaptic region $[86,87]$.

Furthermore, other compounds, in addition to tau or $A \beta$ peptide, may be involved in synaptic dysfunction or, in general, in the development of 
AD. In this regard, recent studies are looking into the involvement of somatic mutations in the onset of the disease [88]. Preliminary results in brain tissue from AD patients have indicated the presence of mutations in some genes related to protein degradation [89].

\section{CONCLUSIONS AND ACKNOWLEDGEMENTS}

This is a short review of some of the work on tau performed by my group. In this regard, I wish to acknowledge the contributions of all those who have passed through my laboratory since it was set up in 1977 for their invaluable contributions. Also, I wish to express my deepest gratitude to all the members of my laboratory. In some of our research lines on tau/AD, we collaborate with Dr. Perry, an outstanding scientist and person.

Also, much of our work has been based on reading and learning from articles after attending talks or discussions or listening to invited speakers in conferences. In this regard, I have known many scientists whose work I have followed at least once. I also wish to acknowledge them, even when some of them sometimes rejected our papers (hopefully for a good reason). Sorry, if I have not included more of their articles in the list of references.

\section{DISCLOSURE STATEMENT}

The author's disclosure is available online (http://jalz.com/manuscript-disclosures/17-0600r1).

\section{REFERENCES}

[1] Avila J (1990) Microtubule dynamics. FASEB J 4, 32843290.

[2] Kirschner M, Mitchison T (1986) Beyond self-assembly: From microtubules to morphogenesis. Cell 45, 329-342.

[3] Weisenberg RC (1972) Microtubule formation in vitro in solutions containing low calcium concentrations. Science 177, 1104-1105.

[4] Matus A (1988) Microtubule-associated proteins: Their potential role in determining neuronal morphology. Annu Rev Neurosci 11, 29-44.

[5] Weingarten MD, Lockwood AH, Hwo SY, Kirschner MW (1975) A protein factor essential for microtubule assembly. Proc Natl Acad Sci U S A 72, 1858-1862.

[6] Serrano L, de la Torre J, Maccioni RB, Avila J (1984) Involvement of the carboxyl-terminal domain of tubulin in the regulation of its assembly. Proc Natl Acad Sci U S A 81, 5989-5993.

[7] Lee G, Cowan N, Kirschner M (1988) The primary structure and heterogeneity of tau protein from mouse brain. Science 239, 285-288.
[8] Guo T, Noble W, Hanger DP (2017) Roles of tau protein in health and disease. Acta Neuropathol 133, 665-704.

[9] Hernandez F, Perez M, Lucas JJ, Mata AM, Bhat R, Avila J (2004) Glycogen synthase kinase-3 plays a crucial role in tau exon 10 splicing and intranuclear distribution of SC35. Implications for Alzheimer's disease. J Biol Chem 279, 3801-3806.

[10] Himmler A (1989) Structure of the bovine tau gene: Alternatively spliced transcripts generate a protein family. Mol Cell Biol 9, 1389-1396.

[11] Garcia de Ancos J, Correas I, Avila J (1993) Differences in microtubule binding and self-association abilities of bovine brain tau isoforms. J Biol Chem 268, 7976-7982.

[12] Jeganathan S, Hascher A, Chinnathambi S, Biernat J, Mandelkow EM, Mandelkow E (2008) Proline-directed pseudo-phosphorylation at AT8 and PHF1 epitopes induces a compaction of the paperclip folding of Tau and generates a pathological (MC-1) conformation. J Biol Chem 283, 32066-32076.

[13] Melo AM, Coraor J, Alpha-Cobb G, Elbaum-Garfinkle S, Nath A, Rhoades E (2016) A functional role for intrinsic disorder in the tau-tubulin complex. Proc Natl Acad Sci U S A 113, 14336-14341.

[14] Thurston VC, Pena P, Pestell R, Binder LI (1997) Nucleolar localization of the microtubule-associated protein tau in neuroblastomas using sense and anti-sense transfection strategies. Cell Motil Cytoskeleton 38, 100-110.

[15] Sultan A, Nesslany F, Violet M, Begard S, Loyens A, Talahari S, Mansuroglu Z, Marzin D, Sergeant N, Humez S, Colin M, Bonnefoy E, Buee L, Galas MC (2011) Nuclear tau, a key player in neuronal DNA protection. J Biol Chem 286, 4566- 4575 .

[16] Corces VG, Salas J, Salas ML, Avila J (1978) Binding of microtubule proteins to DNA: Specificity of the interaction. Eur J Biochem 86, 473-479.

[17] Villasante A, Corces VG, Manso-Martinez R, Avila J (1981) Binding of microtubule protein to DNA and chromatin: Possibility of simultaneous linkage of microtubule to nucleic and assembly of the microtubule structure. Nucleic Acids Res 9, 895-908.

[18] Arrasate M, Perez M, Avila J (2000) Tau dephosphorylation at tau-1 site correlates with its association to cell membrane. Neurochem Res 25, 43-50.

[19] Brandt R, Leger J, Lee G (1995) Interaction of tau with the neural plasma membrane mediated by tau's amino-terminal projection domain. J Cell Biol 131, 1327-1340.

[20] Dotti CG, Banker GA, Binder LI (1987) The expression and distribution of the microtubule-associated proteins tau and microtubule-associated protein 2 in hippocampal neurons in the rat in situ and in cell culture. Neuroscience $\mathbf{2 3}$, 121-130.

[21] Ittner LM, Ke YD, Delerue F, Bi M, Gladbach A, van Eersel J, Wolfing H, Chieng BC, Christie MJ, Napier IA, Eckert A, Staufenbiel M, Hardeman E, Gotz J (2010) Dendritic function of tau mediates amyloid-beta toxicity in Alzheimer's disease mouse models. Cell 142, 387-397.

[22] Sayas CL, Tortosa E, Bollati F, Ramirez-Rios S, Arnal I, Avila J (2015) Tau regulates the localization and function of End-binding proteins 1 and 3 in developing neuronal cells. J Neurochem 133, 653-667.

[23] Llorens-Martin M, Lopez-Domenech G, Soriano E, Avila J (2011) GSK3beta is involved in the relief of mitochondria pausing in a tau-dependent manner. PLoS One 6, e27686.

[24] Correas I, Padilla R, Avila J (1990) The tubulin-binding sequence of brain microtubule-associated proteins, tau and 
MAP-2, is also involved in actin binding. Biochem J 269, 61-64.

[25] Perez M, Arrasate M, Montejo De Garcini E, Munoz V, Avila J (2001) In vitro assembly of tau protein: Mapping the regions involved in filament formation. Biochemistry 40, 5983-5991.

[26] Perez M, Valpuesta JM, Medina M, Montejo de Garcini E, Avila J (1996) Polymerization of tau into filaments in the presence of heparin: The minimal sequence required for tau-tau interaction. J Neurochem 67, 1183-1190.

[27] Arrasate M, Perez M, Valpuesta JM, Avila J (1997) Role of glycosaminoglycans in determining the helicity of paired helical filaments. Am J Pathol 151, 1115-1122.

[28] Gomez-Ramos A, Diaz-Hernandez M, Rubio A, MirasPortugal MT, Avila J (2008) Extracellular tau promotes intracellular calcium increase through M1 and M3 muscarinic receptors in neuronal cells. Mol Cell Neurosci 37, 673-681.

[29] Hernandez F, Cuadros R, Avila J (2004) Zeta 14-3-3 protein favours the formation of human tau fibrillar polymers. Neurosci Lett 357, 143-146.

[30] Ramirez-Rios S, Denarier E, Prezel E, Vinit A, StoppinMellet V, Devred F, Barbier P, Peyrot V, Sayas CL, Avila J, Peris L, Andrieux A, Serre L, Fourest-Lieuvin A, Arnal I (2016) Tau antagonizes EB tracking at microtubule ends through a phosphorylation-dependent mechanism. Mol Biol Cell 27, 2924-2931.

[31] Perez M, Santa-Maria I, Gomez de Barreda E, Zhu X, Cuadros R, Cabrero JR, Sanchez-Madrid F, Dawson HN, Vitek MP, Perry G, Smith MA, Avila J (2009) Tau-an inhibitor of deacetylase HDAC6 function. J Neurochem 109, 1756-1766.

[32] Ding H, Dolan PJ, Johnson GV (2008) Histone deacetylase 6 interacts with the microtubule-associated protein tau. J Neurochem 106, 2119-2130.

[33] Perez M, Valpuesta JM, de Garcini EM, Quintana C, Arrasate M, Lopez Carrascosa JL, Rabano A, Garcia de Yebenes J, Avila J (1998) Ferritin is associated with the aberrant tau filaments present in progressive supranuclear palsy. Am J Pathol 152, 1531-1539.

[34] Grundke-Iqbal I, Iqbal K, Quinlan M, Tung YC, Zaidi MS, Wisniewski HM (1986) Microtubule-associated protein tau. A component of Alzheimer paired helical filaments. J Biol Chem 261, 6084-6089.

[35] Kosik KS, Joachim CL, Selkoe DJ (1986) Microtubuleassociated protein tau (tau) is a major antigenic component of paired helical filaments in Alzheimer disease. Proc Natl Acad Sci U S A 83, 4044-4048.

[36] Wood JG, Mirra SS, Pollock NJ, Binder LI (1986) Neurofibrillary tangles of Alzheimer disease share antigenic determinants with the axonal microtubule-associated protein tau (tau). Proc Natl Acad Sci U S A 83, 4040-4043.

[37] Montejo de Garcini E, Carrascosa JL, Correas I, Nieto A, Avila J (1988) Tau factor polymers are similar to paired helical filaments of Alzheimer's disease. FEBS Lett 236, 150-154.

[38] Montejo de Garcini E, Serrano L, Avila J (1986) Self assembly of microtubule associated protein tau into filaments resembling those found in Alzheimer disease. Biochem Biophys Res Commun 141, 790-796.

[39] Wille H, Drewes G, Biernat J, Mandelkow EM, Mandelkow E (1992) Alzheimer-like paired helical filaments and antiparallel dimers formed from microtubule-associated protein tau in vitro. J Cell Biol 118, 573-584.
[40] Goedert M, Wischik CM, Crowther RA, Walker JE, Klug A (1988) Cloning and sequencing of the cDNA encoding a core protein of the paired helical filament of Alzheimer disease: Identification as the microtubule-associated protein tau. Proc Natl Acad Sci U S A 85, 4051-4055.

[41] Wischik CM, Novak M, Edwards PC, Klug A, Tichelaar W, Crowther RA (1988) Structural characterization of the core of the paired helical filament of Alzheimer disease. Proc Natl Acad Sci U S A 85, 4884-4888.

[42] Goedert M, Jakes R, Spillantini MG, Hasegawa M, Smith MJ, Crowther RA (1996) Assembly of microtubuleassociated protein tau into Alzheimer-like filaments induced by sulphated glycosaminoglycans. Nature 383, 550-553.

[43] Ledesma MD, Bonay P, Colaco C, Avila J (1994) Analysis of microtubule-associated protein tau glycation in paired helical filaments. J Biol Chem 269, 21614-21619.

[44] Alzheimer (1907) Uber eine eigenartige Erkankung der Hirnrinde. Allg Z Psychiatr Psychisch-gerichtliche Med 64, 146-148.

[45] Avila J (2010) Alzheimer disease: Caspases first. Nat Rev Neurol 6, 587-588.

[46] Grundke-Iqbal I, Iqbal K, Tung YC, Quinlan M, Wisniewski HM, Binder LI (1986) Abnormal phosphorylation of the microtubule-associated protein tau (tau) in Alzheimer cytoskeletal pathology. Proc Natl Acad Sci U S A 83, 49134917.

[47] Gomez-Ramos A, Diaz-Hernandez M, Cuadros R, Hernandez F, Avila J (2006) Extracellular tau is toxic to neuronal cells. FEBS Lett 580, 4842-4850.

[48] Simon D, Garcia-Garcia E, Royo F, Falcon-Perez JM, Avila J (2012) Proteostasis of tau. Tau overexpression results in its secretion via membrane vesicles. FEBS Lett 586, 47-54.

[49] Gomez-Ramos A, Diaz-Hernandez M, Rubio A, DiazHernandez JI, Miras-Portugal MT, Avila J (2009) Characteristics and consequences of muscarinic receptor activation by tau protein. Eur Neuropsychopharmacol 19, 708-717.

[50] Frost B, Jacks RL, Diamond MI (2009) Propagation of tau misfolding from the outside to the inside of a cell. $J$ Biol Chem 284, 12845-12852.

[51] Clavaguera F, Bolmont T, Crowther RA, Abramowski D, Frank S, Probst A, Fraser G, Stalder AK, Beibel M, Staufenbiel M, Jucker M, Goedert M, Tolnay M (2009) Transmission and spreading of tauopathy in transgenic mouse brain. Nat Cell Biol 11, 909-913.

[52] Holmes BB, DeVos SL, Kfoury N, Li M, Jacks R, Yanamandra K, Ouidja MO, Brodsky FM, Marasa J, Bagchi DP, Kotzbauer PT, Miller TM, Papy-Garcia D, Diamond MI (2013) Heparan sulfate proteoglycans mediate internalization and propagation of specific proteopathic seeds. Proc Natl Acad Sci U S A 110, E3138-E3147.

[53] Diaz-Hernandez M, Gomez-Ramos A, Rubio A, GomezVillafuertes R, Naranjo JR, Miras-Portugal MT, Avila J (2010) Tissue-nonspecific alkaline phosphatase promotes the neurotoxicity effect of extracellular tau. J Biol Chem $\mathbf{2 8 5}, 32539-32548$.

[54] Alonso AC, Grundke-Iqbal I, Iqbal K (1996) Alzheimer's disease hyperphosphorylated tau sequesters normal tau into tangles of filaments and disassembles microtubules. Nat Med 2, 783-787.

[55] Avila J, Lucas JJ, Perez M, Hernandez F (2004) Role of tau protein in both physiological and pathological conditions. Physiol Rev 84, 361-384.

[56] Ishiguro K, Shiratsuchi A, Sato S, Omori A, Arioka M, Kobayashi S, Uchida T, Imahori K (1993) Glycogen 
synthase kinase 3 beta is identical to tau protein kinase I generating several epitopes of paired helical filaments. FEBS Lett 325, 167-172.

[57] Hanger DP, Anderton BH, Noble W (2009) Tau phosphorylation: The therapeutic challenge for neurodegenerative disease. Trends Mol Med 15, 112-119.

[58] Lucas JJ, Hernandez F, Gomez-Ramos P, Moran MA, Hen R, Avila J (2001) Decreased nuclear beta-catenin, tau hyperphosphorylation and neurodegeneration in GSK-3beta conditional transgenic mice. EMBO J 20, 27-39.

[59] Hernandez F, Borrell J, Guaza C, Avila J, Lucas JJ (2002) Spatial learning deficit in transgenic mice that conditionally over-express GSK-3beta in the brain but do not form tau filaments. J Neurochem 83, 1529-1533.

[60] Llorens-Martin M, Fuster-Matanzo A, Teixeira CM, JuradoArjona J, Ulloa F, Defelipe J, Rabano A, Hernandez F, Soriano E, Avila J (2013) GSK-3beta overexpression causes reversible alterations on postsynaptic densities and dendritic morphology of hippocampal granule neurons in vivo. $\mathrm{Mol}$ Psychiatry 18, 451-460.

[61] Llorens-Martin M, Jurado-Arjona J, Fuster-Matanzo A, Hernandez F, Rabano A, Avila J (2014) Peripherally triggered and GSK-3beta-driven brain inflammation differentially skew adult hippocampal neurogenesis, behavioral pattern separation and microglial activation in response to ibuprofen. Transl Psychiatry 4, e463.

[62] Chen J, Kanai Y, Cowan NJ, Hirokawa N (1992) Projection domains of MAP2 and tau determine spacings between microtubules in dendrites and axons. Nature 360, 674-677.

[63] Dawson HN, Ferreira A, Eyster MV, Ghoshal N, Binder LI, Vitek MP (2001) Inhibition of neuronal maturation in primary hippocampal neurons from tau deficient mice. J Cell Sci 114, 1179-1187.

[64] Pallas-Bazarra N, Jurado-Arjona J, Navarrete M, Esteban JA, Hernandez F, Avila J, Llorens-Martin M (2016) Novel function of Tau in regulating the effects of external stimuli on adult hippocampal neurogenesis. EMBO J 35, 14171436.

[65] Pallas-Bazarra N, Kastanauskaite A, Avila J, DeFelipe J, Llorens-Martin M (2017) GSK-3beta overexpression alters the dendritic spines of developmentally generated granule neurons in the mouse hippocampal dentate gyrus. Front Neuroanat 11, 18.

[66] Kimura T, Whitcomb DJ, Jo J, Regan P, Piers T, Heo S, Brown C, Hashikawa T, Murayama M, Seok H, Sotiropoulos I, Kim E, Collingridge GL, Takashima A, Cho K (2014) Microtubule-associated protein tau is essential for long-term depression in the hippocampus. Philos Trans R Soc Lond B Biol Sci 369, 20130144.

[67] Illenberger D, Schwald F, Gierschik P (1997) Characterization and purification from bovine neutrophils of a soluble guanine-nucleotide-binding protein that mediates isozyme-specific stimulation of phospholipase $\mathrm{C}$ beta2. Eur J Biochem 246, 71-77.

[68] Godemann R, Biernat J, Mandelkow E, Mandelkow EM (1999) Phosphorylation of tau protein by recombinant GSK3beta: Pronounced phosphorylation at select Ser/Thr-Pro motifs but no phosphorylation at Ser262 in the repeat domain. FEBS Lett 454, 157-164.

[69] Ittner A, Chua SW, Bertz J, Volkerling A, van der Hoven J, Gladbach A, Przybyla M, Bi M, van Hummel A, Stevens CH, Ippati S, Suh LS, Macmillan A, Sutherland G, Kril JJ, Silva AP, Mackay J, Poljak A, Delerue F, Ke YD, Ittner LM (2016) Site-specific phosphorylation of tau inhibits amyloid-beta toxicity in Alzheimer's mice. Science 354, 904-908.

[70] Miyamoto T, Stein L, Thomas R, Djukic B, Taneja P, Knox J, Vossel K, Mucke L (2017) Phosphorylation of tau at Y18, but not tau-fyn binding, is required for tau to modulate NMDA receptor-dependent excitotoxicity in primary neuronal culture. Mol Neurodegener 12, 41.

[71] Cantero JL, Hita-Yanez E, Moreno-Lopez B, Portillo F, Rubio A, Avila J (2010) Tau protein role in sleep-wake cycle. J Alzheimers Dis 21, 411-421.

[72] Marciniak E, Leboucher A, Caron E, Ahmed T, Tailleux A, Dumont J, Issad T, Gerhardt E, Pagesy P, Vileno M, Bournonville C, Hamdane M, Bantubungi K, Lancel S, Demeyer D, Eddarkaoui S, Vallez E, Vieau D, Humez S, Faivre E, Grenier-Boley B, Outeiro TF, Staels B, Amouyel P, Balschun D, Buee L, Blum D (2017) Tau deletion promotes brain insulin resistance. J Exp Med 214, 2257-2269.

[73] Planel E, Miyasaka T, Launey T, Chui DH, Tanemura K, Sato S, Murayama O, Ishiguro K, Tatebayashi Y, Takashima A (2004) Alterations in glucose metabolism induce hypothermia leading to tau hyperphosphorylation through differential inhibition of kinase and phosphatase activities: Implications for Alzheimer's disease. J Neurosci 24, 2401-2411.

[74] Avila J, Diaz-Nido J (2004) Tangling with hypothermia. Nat Med 10, 460-461.

[75] Lei P, Ayton S, Finkelstein DI, Spoerri L, Ciccotosto GD, Wright DK, Wong BX, Adlard PA, Cherny RA, Lam LQ, Roberts BR, Volitakis I, Egan GF, McLean CA, Cappai R, Duce JA, Bush AI (2012) Tau deficiency induces parkinsonism with dementia by impairing APP-mediated iron export. Nat Med 18, 291-295.

[76] Fernandez-Nogales M, Cabrera JR, Santos-Galindo M, Hoozemans JJ, Ferrer I, Rozemuller AJ, Hernandez F, Avila J, Lucas JJ (2014) Huntington's disease is a four-repeat tauopathy with tau nuclear rods. Nat Med 8, 881-885.

[77] Okbay A, Beauchamp JP, Fontana MA, Lee JJ, Pers TH, Rietveld CA, Turley P, Chen GB, Emilsson V, Meddens SF, Oskarsson S, Pickrell JK, Thom K, Timshel P, de Vlaming R, Abdellaoui A, Ahluwalia TS, Bacelis J, Baumbach C, Bjornsdottir G, Brandsma JH, Pina Concas M, Derringer J, Furlotte NA, Galesloot TE, Girotto G, Gupta R, Hall LM, Harris SE, Hofer E, Horikoshi M, Huffman JE, Kaasik K, Kalafati IP, Karlsson R, Kong A, Lahti J, van der Lee SJ, deLeeuw C, Lind PA, Lindgren KO, Liu T, Mangino M, Marten J, Mihailov E, Miller MB, van der Most PJ, Oldmeadow C, Payton A, Pervjakova N, Peyrot WJ, Qian Y, Raitakari O, Rueedi R, Salvi E, Schmidt B, Schraut KE, Shi J, Smith AV, Poot RA, St Pourcain B, Teumer A, Thorleifsson G, Verweij N, Vuckovic D, Wellmann J, Westra HJ, Yang J, Zhao W, Zhu Z, Alizadeh BZ, Amin N, Bakshi A, Baumeister SE, Biino G, Bønnelykke K, Boyle PA, Campbell H, Cappuccio FP, Davies G, De Neve JE, Deloukas P, Demuth I, Ding J, Eibich P, Eisele L, Eklund N, Evans DM, Faul JD, Feitosa MF, Forstner AJ, Gandin I, Gunnarsson B, Halldórsson BV, Harris TB, Heath AC, Hocking LJ, Holliday EG, Homuth G, Horan MA, Hottenga JJ, de Jager PL, Joshi PK, Jugessur A, Kaakinen MA, Kähönen M, Kanoni S, Keltigangas-Järvinen L, Kiemeney LA, Kolcic I, Koskinen S, Kraja AT, Kroh M, Kutalik Z, Latvala A, Launer LJ, Lebreton MP, Levinson DF, Lichtenstein P, Lichtner P, Liewald DC, LifeLines Cohort Study, Loukola A, Madden PA, Mägi R, Mäki-Opas T, Marioni RE, Marques-Vidal P, Meddens GA, McMahon G, Meisinger C, Meitinger T, Milaneschi Y, Milani L, Montgomery GW, Myhre R, Nelson 
CP, Nyholt DR, Ollier WE, Palotie A, Paternoster L, Pedersen NL, Petrovic KE, Porteous DJ, Räikkönen K, Ring SM, Robino A, Rostapshova O, Rudan I, Rustichini A, Salomaa V, Sanders AR, Sarin AP, Schmidt H, Scott RJ, Smith BH, Smith JA, Staessen JA, Steinhagen-Thiessen E, Strauch K, Terracciano A, Tobin MD, Ulivi S, Vaccargiu S, Quaye L, van Rooij FJ, Venturini C, Vinkhuyzen AA, Völker U, Völzke H, Vonk JM, Vozzi D, Waage J, Ware EB, Willemsen G, Attia JR, Bennett DA, Berger K, Bertram L, Bisgaard H, Boomsma DI, Borecki IB, Bültmann U, Chabris CF, Cucca F, Cusi D, Deary IJ, Dedoussis GV, van Duijn CM, Eriksson JG, Franke B, Franke L, Gasparini P, Gejman PV, Gieger C, Grabe HJ, Gratten J, Groenen PJ, Gudnason V, van der Harst P, Hayward C, Hinds DA, Hoffmann W, Hyppönen E, Iacono WG, Jacobsson B, Järvelin MR, Jöckel KH, Kaprio J, Kardia SL, Lehtimäki T, Lehrer SF, Magnusson PK, Martin NG, McGue M, Metspalu A, Pendleton N, Penninx BW, Perola M, Pirastu N, Pirastu M, Polasek O, Posthuma D, Power C, Province MA, Samani NJ, Schlessinger D, Schmidt R, Sørensen TI, Spector TD, Stefansson K, Thorsteinsdottir U, Thurik AR, Timpson NJ, Tiemeier H, Tung JY, Uitterlinden AG, Vitart V, Vollenweider P, Weir DR, Wilson JF, Wright AF, Conley DC, Krueger RF, Davey Smith G, Hofman A, Laibson DI, Medland SE, Meyer MN, Yang J, Johannesson M, Visscher PM, Esko T, Koellinger PD, Cesarini D, Benjamin DJ (2016) Genome-wide association study identifies 74 loci associated with educational attainment. Nature $\mathbf{5 3 3}$, 539-542.

[78] Coupland KG, Kim WS, Halliday GM, Hallupp M, DobsonStone C, Kwok JB (2016) Role of the long non-coding RNA MAPT-AS1 in regulation of microtubule associated protein tau (MAPT) expression in Parkinson's disease. PLoS One 11, e0157924.

[79] Hernandez F, Avila J (2017) Commentary: Genome-wide association study identifies 74 loci associated with educational attainment. Front Mol Neurosci 10, 23.

[80] Yin Y, Gao D, Wang Y, Wang ZH, Wang X, Ye J, Wu D, Fang L, Pi G, Yang Y, Wang XC, Lu C, Ye K, Wang JZ (2016) Tau accumulation induces synaptic impairment and memory deficit by calcineurin-mediated inactivation of nuclear CaMKIV/CREB signaling. Proc Natl Acad Sci U S A 113, E3773-E3781.

[81] Young ZT, Mok SA, Gestwicki JE (2017) Therapeutic strategies for restoring tau homeostasis. Cold Spring Harb Perspect Med, doi: 10.1101/cshperspect.a024612

[82] Walker LC, Jucker M (2017) The exceptional vulnerability of humans to Alzheimer's disease. Trends Mol Med 23, 534545.

[83] Leon-Espinosa G, Garcia E, Gomez-Pinedo U, Hernandez F, DeFelipe J, Avila J (2016) Decreased adult neurogenesis in hibernating Syrian hamster. Neuroscience 333, 181-192.

[84] Arendt T, Stieler J, Strijkstra AM, Hut RA, Rudiger J, Van der Zee EA, Harkany T, Holzer M, Hartig W (2003) Reversible paired helical filament-like phosphorylation of tau is an adaptive process associated with neuronal plasticity in hibernating animals. J Neurosci 23, 6972-6981.

[85] Nelson PT, Stefansson K, Gulcher J, Saper CB (1996) Molecular evolution of tau protein: Implications for Alzheimer's disease. J Neurochem 67, 1622-1632.

[86] Moreno H, Morfini G, Buitrago L, Ujlaki G, Choi S, Yu E, Moreira JE, Avila J, Brady ST, Pant H, Sugimori M, Llinas RR (2016) Tau pathology-mediated presynaptic dysfunction. Neuroscience 325, 30-38.

[87] Florenzano F, Veronica C, Ciasca G, Ciotti MT, Pittaluga A, Olivero G, Feligioni M, Iannuzzi F, Latina V, Sciacca MFM, Sinopoli A, Milardi D, Pappalardo G, De Spirito M, Papi M, Atlante A, Bobba A, Borreca A, Calissano P, Amadoro G (2017) Extracellular truncated tau causes early presynaptic dysfunction associated with Alzheimer's disease and other tauopathies. Oncotarget, doi: 10.18632/oncotarget.17371

[88] Gomez-Ramos A, Picher AJ, Garcia E, Garrido P, Hernandez F, Soriano E, Avila J (2017) Validation of suspected somatic single nucleotide variations in the brain of Alzheimer's disease patients. J Alzheimers Dis 56, 977-990.

[89] Gomez-Ramos A, Podlesniy P, Soriano E, Avila J (2015) Distinct X-chromosome SNVs from some sporadic AD samples. Sci Rep 5, 18012. 